\title{
9.4 Маркетинг в публічному управлінні: стратегія національного бренду
}

Глобалізація світової економіки, збільшення міжнародної конкуренції, активізація інноваційних процесів, вимагають нових підходів до розвитку процесів взаємодії маркетингу та публічного управління.

Взаємодія маркетингу та публічного управління має прояв в розвитку маркетингу як управлінської діяльності, концепції та науково-освітнього напряму. Маркетинг сьогодні в розвинених країнах трактується не лише як концепція маркетингу, яка застосовується в сфері публічного управління 3 певним набором притаманних ій специфічних інструментів і технологій, а i осмислюється як філософія публічного управління, творча управлінська діяльність, концептуальний підхід до розроблення загальних орієнтирів i цінностей суспільства. У сучасному науковому дискурсі з питань розвитку маркетингу прийнято виокремлювати два шляхи взаємопроникнення маркетингу та публічного управління. Перший полягає у «дифузії» публічного управління в маркетингові технології. Другий, який відбувається паралельно в історичному контексті, формує практику поступового проникнення маркетингового підходу в практику публічного управління [470].

Зауважимо, що використання технологій маркетингу в публічному управлінні у більшості країн відбувалось саме через комунікації (рекламу, паблік рилейшнз, пропаганду тощо). У кожній країні, в кожний історичний період вони були агресивні чи завуальовані, жорсткі чи гнучкі. Уряди країн застосовували такий інструментарій, який дозволяв швидко та безпомилково досягати чітко визначених цілей - від відвертої пропаганди до використання технологій нейролінгвістичного програмування.

Сьогодні майже всі уряди, публічні діячі, громадськість усвідомлюють необхідність корегування сприйняття, становлення і розвитку бренду країни, вважаючи, що цей процес слід починати зі зміни ставлення самих громадян до своєї країни. 
Так, на жаль, міжнародна спільнота сприймає Україну як країну, де ідуть бойові дії, панує корупція, влада олігархів і відбуваються політичні скандали.

В цій ситуації, просування національних інтересів і бренду “Україна" - це стратегічні інвестиції в наше майбутнє. Успіх економічного зростання та динамічний розвиток відносин з іншими державами багато в чому залежить від того, як буде сформований і як буде просуватися на внутрішньому та світовому ринках бренд країни.

Створення позитивного іміджу країни, розвиток національного бренду, стратегічне позиціонування його на міжнародній арені має стати невід’ємною складовою публічної політики в Україні.

Концепція національного брендингу з'явилась безпосередньо на основі розвитку бізнес брендингу. Саймон Анхольт визначає брендинг країни як систематичний процес узгодження дій, поведінки, інвестицій, інновацій i комунікацій країни для реалізації стратегії конкурентної ідентичності. Бренд країни являє собою ту асоціативну модель, яку містить свідомість індивіда (як мешканця цієї країни, так і громадянина іншої) та до якої він апелює, почувши назву країни [471].

Теорія державного (національного) брендингу бере початок із визначення, аналізу та наукового осмислення чотирьох основних концептуальних категорій, а саме - країна походження, брендинг території, публічна дипломатія та національна ідентичність [472].

За визначення Всесвітньої організації туризму, бренд держави - це сукупність емоційних і раціональних уявлень, що є результатом зіставлення усіх ознак країни, власного досвіду й чуток, що впливають на створення певного образу про неї. Національний брендинг - імідж країни на міжнародній арені у політичному, економічному, культурному вимірах.

Незважаючи на наявність альтернативних підходів до дефініції брендингу, головна його ідея пов'язана 3 продукуванням стійких відмітних властивостей об’єкта або суб'єкта брендингу, а отже, прямо пов'язана з реалізацією стратегії диференціації на конкурентному ринку. Іншими словами, у випадку 
національного брендингу, вона пов'язана зі створенням та розвитком унікального, добре знаного на міжнародній арені національного бренду.

Якщо порівнювати бренд з іміджом, то перше поняття є більш стійким. Імідж держави - це змінна складова бренду, яка означає образ, на який намагаються впливати з метою зміни. Відповідно при згадуванні назви держави (бренду країни) відразу ж виникає цілий ланцюг асоціацій стосовно цієї країни, наприклад: обіцянки щодо очікуваної стабільності, безпеки, гостинності, привабливості для проживання та відпочинку; врахування накопиченого досвід; асоціювання з високим рівнем якості і цінності; провокування встановлення тривалих, що грунтуються на взаємній довірі, відносин; гарантування збільшення доходів країни. Дослідження підтверджують, що країни з сильними брендами здатні ефективніше будувати економічну вартість та експортувати власні продукти; залучати інвестиції, туристів і таланти; змінювати стереотипи і будувати власні конкурентні переваги, такі як: Японія - це високотехнологічний бренд, Франція - бренд країни високої моди та вишуканого смаку, Швейцарія світовий банк, міжнародний сейф, Австрія - країна вальсу, Данія - країна казки і Русалоньки.

Т. Нагорняк вважає, що актуальним для України стане національний брендинг країни через формування іміджу іï регіонів, який включатиме таку послідовність етапів:

• аудит бренду “Україна” та оцінка іміджу іiі регіонів;

- розробка програми формування іміджу регіонів та бренду

«Україна»;

- заходи впровадження програми іміджування регіонів та брендингу країни у межах власних кордонів та у світі [473].

В грунтовному досліджені [474], наразі виділяють сім етапів трансформації концепції брендингу:

1. (1860-1920 pp.) - ідентифікаційний брендинг, що сприяв визначенню продуктової категорії та позиціонуванню товарів та послуг з акцентом уваги на їх якості, складі, цінових характеристиках; 
2. (1920-1930 рр.) - брендинг вигод, що передбачав презентацію не тільки якостей, але і вигод від товару або послуги;

3. (1930-1960 pp.) - «символічний» брендинг, пов'язаний 3 персоналізацією та акцентуванням уваги на іміджі, життєвому стилі, цінностях особистості користувача/покупця;

4. (1960-1980 pp.) - брендинг «досвіду», який передбачає звернення до позитивного досвіду сприйняття та грунтується на технології мультисенсорного (звук, вигляд, смак, запах, тактильні відчуття, навіювання думок) формування та розвитку цього досвіду;

5. (1980-1990 рр.) - «соціальний» брендинг, що акцентував увагу на соціальних факторах, у т. ч. соціальній відповідальності;

6. (1990-2005рр.) - «тотальний» брендинг, який перетворюється 3 маркетингового інструменту в інструмент стратегічного управління та передбачає наявність інтегрованої системи фізичного, психологічного та соціального впливу;

7. (2005 р. - донині) - креативний багатогранний брендинг, що передбачає широке використання нейромаркетингових технологій у процесі брендингу та абсолютний необмежений доступ до застосування будь-яких інновацій та цифрових технологій для формування асоціативного сприйняття будь-якої сфери діяльності, будь-якого об'єкта чи системи з урахуванням еко-, соціо-, кібер- і т.п. пріоритетів у локальному, регіональному, національному, міжнародному або навіть глобальному просторі.

Державний бренд поширюється за допомогою логотипів, слоганів, через інформаційні кампанії, проте цього замало. Важливим є його сприйняття та постійна ретрансляція громадянами усіх верств суспільства.

Так, Саймон Анхольт пропонує поєднувати сили, які формують бренд будь-якої держави, а саме:

•багатство культурної та історичної спадщини;

•ефективність державного управління;

• інвестиційна перспективність країни; 
•якість експортованих товарів;

•населення країни (людський капітал);

•туризм (туристичний потенціал) [471].

Ще один британський дослідник В. Оллінс підкреслює, що в основі національного бренду повинна лежати ключова ідея, яка буде проектувати національні характеристики країни ефективним та привабливим способом. Ця ключова ідея повинна виконувати наступні завдання:

- $\quad$ вона повинна працювати на емоційному і раціональному рівнях, щоб апелювати як «до серця, так і до розуму людей»;

- $\quad$ ключова ідея повинна бути релевантна для всіх аудиторій бренду;

- ключова ідея повинна бути чітко сформульованою;

- $\quad$ ключова ідея повинна бути правдивою, щоб аудиторія визнавала їі як реалістичну [475].

В основі національного бренду можуть лежати ключові ідеї різної спрямованості. Щодо вектору спрямованості бренду держави існують два підходи:

- бренд держави розглядається як зовнішньоорієнтований феномен. Він $€$ носієм або провідником у зовнішній світ ідей, якою є конкретна країна;

- бренд держави є одночасно і внутрішньо- і зовнішньоорієнтованим феноменом.

Незалежно від того, яка ідея буде обрана, слід пам'ятати про те, що важливо цілеспрямовано і систематично просувати ï у світове співтовариство. Навіть одна подія, яка суперечить загальній концепції бренду, може призвести до руйнування цілісного образу країни. Саме тому процесу трансляції державного бренду завжди має передувати аналітична робота, яка дозволить зрозуміти, які уявлення про країну вже існують у світі, визначити основних носіїв даних уявлень та з'ясувати причини формування цих уявлень. Тому сьогодні домінує сприйняття бренду країни , як асоціативної моделі, образу, суми уявлень про країну у свідомості вітчизняних та іноземних споживачів (стейкхолдерів). Водночас, брендинг країни розглядають як процес, спрямований на реалізацію 
стратегії національної безпеки, посилення національної ідентичності, підтримки конкурентоспроможності країни шляхом комунікації зі стейкхолдерами.

Сьогодні існує два впливових міжнародних рейтингів брендів держав Nation Brand Index (Anholft GFK) та Country Brand Index (FutureBrand). Методологія їх складання відрізняється:

- Nation Brands Index розглядає шість критеріїв: туризм, експорт, люди, влада, культура та історична спадщина, інвестиції та імміграція;

- Рейтинг Country Brands Index використовує ієрархічну модель рішень, за допомогою якої бренд оцінюється у таких вимірах:

• обізнаність (чи відомо, що така країна існує),

•знайомство (як добре респондент знає про країну),

•асоціації (туризм, культурний спадок, якість життя, система цінностей),

•повага (наскільки країна викликає пошану),

• міркування (чи розглядалася країна як місце, яке варто відвідати),

• рішення про візит (що спонукає до його прийняття),

•бажання респондента переповідати про країну знайомим.

У процесі порівняння методологій можна визначити, так зване, ядро бренду держави, яке визначають як:

- систему держави: політична, економічна та управлінська.

- національний вимір: ментальність населення, культура та історична спадщина.

До атрибутів бренда можна віднести: назву, логотип, слоган, шрифти, кольори, звуковий ряд.

До основних етапів формування бренду держави відносять:

-визначення цілі та завдань державного брендингу;

-визначення цільової аудиторії та способів просування бренду;

-дослідження щодо існуючих стереотипів про країну у цільової аудиторії;

-визначення переваг, очікувань і вимог цільової аудиторії, оригінальні риси та позитивне сприйняття бренду держави; 
-розробка бренду держави;

-розробка стратегія просування бренду та відповідного плану дій, який, має на меті переведення розробленого макету бренду держави у реальні контексти (візуальний, вербальний, комунікативний);

-контроль за впровадженням програми державного брендингу;

-оцінка проміжних результатів;

-корегування у разі необхідності моделі й стратегії державного брендингу та моніторинг ефективності сформованого бренду держави.

У 2015 році Інститут світової політики провів дослідження щодо іміджу України. Дослідження проводилось у шести найбільших за кількістю населення країнах СС У ході дослідження було встановлено, із чим асоціюється Україна: у цілому в невеликих відсотках (від чотирьох і нижче) негативне сприйняття корелюється 3 позитивним. Серед негативних традиційно залишаються криза (загалом), Чорнобильська катастрофа, соціальна нестабільність, насильство, мігранти, корупція, політичні проблеми, вбивства, анархія, Волинська різня, голод, комунізм, страх, геноцид, економічна криза, падіння літака (Малайзійських авіаліній), анексія Криму тощо. Позитивним - дослідники вважають той факт, що, попри агресивну пропаганду Росії, асоціація України 3 фашизмом практично відсутня.

У 2016 році Brand Finance публікує щорічний звіт про вартість національних брендів світу. За результатами звіту Brand Finance Nation Brands 2016, США продовжують домінувати в рейтингу, збільшивши своє зростання на 4\%. У Японії зафіксовано значне зростання серед найбільших світових економік. Ïї брендова вартість зросла на 18\% внаслідок підвищення курсу національної валюти та зростання конкурентоспроможності робочої сили. Вартість національного бренду України, згідно зі звітом, у 2016 році збільшилась на 39\%. завдяки чому у цьому році він став третім серед тих брендів країни, які зростали найшвидше [476].

У звіті відзначається, що у 2016 році Україна продемонструвала відносну стабільність і користувалась меншою (негативною) увагою засобів масової 
інформації, незважаючи на те, що іiі економіка залишалась вразливою внаслідок подальшого протистояння 3 Росією [477]. При цьому, відзначається, що показники сили бренду для безпеки виросли на 18,2\%, разом з цим відбулось підвищення оцінки якості життя на $11.4 \%$, а також суттєве поліпшення здатності країни зберігати свій найталановитіший кадровий потенціал.

Таким чином, слід зазначити, що в основі публічної політики щодо формування національного бренду повинні лежати ключові ідеї різної спрямованості. Ці ідеї слід цілеспрямовано і систематично просувати у світове співтовариство. На сьогодні такими ідеями можуть бути політика інвестиційної привабливості України, прозорі правила ведення бізнесу і залучення капіталу, просування вітчизняного виробника під слоганом «Купуй Українське», розвиток туризму, розвиток міст «Львів зі смаком шоколаду», гірськолижний курорт «Буковель», участь у популярних музичних конкурсах : « Свробачення - 2021», де справжнім відкриттям і амбасадором українських співочих традицій був виступ гурту «GoA», великий резонанс отримала i нова форма українських футболістів на чемпіонаті Свро-2020 із зображенням мапи України з контурами анексованого Криму і тимчасово окупованих території та гаслом «Слава УкраїніГероям слава!». 